\title{
The Perception of Human Cloning: A Comparative Study between Difference Faiths in Malaysia
}

\author{
Mohd Arip Kasmo ${ }^{1}$, Abur Hamdi Usman ${ }^{2}$, Mohamad Mohsin Mohamad Said ${ }^{1}$, Mohamad Taha ${ }^{1}$ \\ \& Azwira Abdul Aziz ${ }^{1}$ \\ ${ }^{1}$ Centre for General Studies, The National University of Malaysia, Malaysia \\ ${ }^{2}$ Institute of Islam Hadhari, The National University of Malaysia \\ Correspondence: Abur Hamdi Usman. Institute of Islam Hadhari, The National University of Malaysia, 43600, \\ Bangi, Selangor, Malaysia. Tel: 60-166-905-082. E-mail: aburhamdiusman@yahoo.com
}

Received: November 19, 2014 Accepted: January 5, 2015 Online Published: February 25, 2015

doi: $10.5539 /$ res.v7n3p178

URL: http://dx.doi.org/10.5539/res.v7n3p178

\begin{abstract}
This paper reports a study on the perception of the Malaysian of different faiths on the issue of human cloning. Altogether 1920 respondents from all over the country participated in the study. Each respondent was given a booklet containing questionnaire about the cloning of human being. The question was provided with five choices of response in the form of Likert style scale, ranging from 1. Strongly disagree, 2. Disagree, 3. Not sure, 4. Agree, and 5. Strongly agree. The raw data obtained were analysed using the SPSS. The data were analysed to obtain the percentage, and mean and the different means were analyzed using t-test to know whether the difference of means were significant or not. The finding show that less than $58.2 \%$ of the respondents perceived that human cloning is against religion. The result of the study has also shown that $62.5 \%$ of the Muslim respondents, $41.3 \%$ of the Christian respondents, $57.25 \%$ of the Buddhists respondents and $40.4 \%$ of the Hindu respondents perceived that human cloning is against religion. The means responses of the respondents based on the religion also differ from each other and was tested with one-way ANOVA, the means differences are significant. Muslim respondents show stronger perception that human cloning is against religion followed by the other respondents of other faiths. Moreover, the mean difference is significant between the mean respondents and the mean responses of the respondents from other faiths.
\end{abstract}

Keywords: human, cloning, perception, faith, Malaysia

\section{Introduction}

The issue of the possibilities of cloning of human and its ethical implications have been debated widely by many people especially scientists, philosophers, religious authorities, and even the lay men throughout the world. In 1997 for example president Clinton asked the National Bioethics Advisory Commission (NBAC) to review the legal and the ethical issue associated with human cloning (Lauritzen, 2001).

The issue of human cloning and its ethical implication have also been widely discussed and debated in Malaysia. In 2002 a nation-wide public conference organized by the Ministry of Foreign Affair at the Institute of Strategic and International Studies of Malaysia was held in Kuala Lumpur in order to discuss questions of human cloning and to formulate Malaysia's position at the negotiations of the United Nation (Roetz, 2006). In Malaysia, the highest religious authority the National Fatwa Council support Embryonic stem cell research based on the saying of the prophet Muhammad that before 120 days the embryo has not been infused yet with the soul (Knowles, 2007). Buddhism and Hinduism on the other hand seem to have different approach toward human cloning. For example, Korean Buddhism forbids killing of life and hence it accepts reproductive human cloning for childless couples while the Thervada-Buddhism in Thailand accepts therapeutic human cloning (Roetz, 2006).

In India, the birth place of Hinduism, and Buddhism biotechnology, including human cloning is undergoing rapid development and this phenomena is in fact contradicts Hinduism percept which forbid human cloning if it involve the death of the embryo (Roetz, 2006). The views of various religions, Islam, Christianity, Buddhism and Hinduism might influence the opinion of the people in Malaysia of different religion, and thus the study is important to gauge the public opinion of human cloning in Malaysia, and definitely this study can be used by the authority to map out planning and prepare future development in biotechnology especially in the field of human 
cloning.

\section{The Notion of Human Cloning: An Analytical Measurement}

Human cloning simply mean producing the identical copy of human being. The idea of human cloning went back in 1963 when the British biologist J. B. S. Halding publicly and explicitly endorsed human cloning (Lauritzen, 2001). The possibility of human cloning re-emerged when the cloned sheep Dolly was born in July 5 , 1996 (MacKinnon, 2000). The news about the birth of Dolly, the cloned lamb was reported at the front page of every newspaper in the world (Pence, 1998).

Debates and discussion on the possibility of cloning human being raged on and the people started to asked question on the ethic and morality of human cloning. The issue of ethics in human cloning was discussed by the World Health Organisation (WHO) for several years although no binding agreement was achieved (Roetz, 2006). The possibilities that human cloning could be successful were raised by President's council of Bioethics who pointed out that $89 \%$ of the cloned mammal which were transferred to recipient females did not come to birth (President's Council of Bioethics, 2002). The news that the South Korean scientist has successfully cloned human embryo, which was probably the first in the world stirred the world, however it was later found out that the scientist has fabricated the research and the paper was subsequently retracted (Johnson, 2011).

In Malaysia, the religious scholar discussed the issues and the discussion was widely circulated in the mass media, leading to the awareness of the people on the issue. Should we clone human because we can? Asked Turner (1997). Human cloning is also being discussed by the religious circle after the successful cloning of the sheep Dolly. The interfaith cooperation in formulating proper response to face the possibility of human cloning was also sought (Sachedina, 2009). The issue of human cloning has also been discussed among universities students. One question which has always been asked is "Is it possible to create such a copy of human". Although the imagination of human being copied is just like a fairy tale by a lot of people, but the possibilities of cloning human could be scientifically explained such as by McLaren (2002).

\subsection{Method of Study}

The study was conducted using the questionnaire method. 1920 respondents of different religions, males and females from the age of 20 to 50 years participated in the study. Each respondent was given a booklet containing questionnaire with statements about human cloning and other related issue. Each statement was provided with responses in the form of Likert type scale, ranging from 1 (strongly disagree), 2 (disagree), 3 (not sure), 4 (agree) and 5 (strongly agree). Likert type scale was used in this study because it measures attitude of the respondents.

Kothari (2011) listed five reasons why Likert scale is good instrument of test. The five reasons are: First, it is relatively easy to construct. Second, it is more reliable instrument because under it, respondents answer each statement included in the instrument. Third, each statement included in the Likert scale is given an empirical test for discriminating ability. Fourth, Likert scale can easily be used. Fifth, it is take less time to construct. In this study the respondents were give 30 minutes to respond to the questionnaire, and the booklet were collected to be analyzed using the Statistical Package for the Social Sciences (SPSS) to obtain the mean responses, the percentages of the responses. The mean difference were also tested using the t-test for the independent samples and also using one-way ANOVA. The means, the percentages and also the t-test result as well as the one-way ANOVA test are presented in the form of tables and diagrams. The results of the analysis are interpreted and discussed at the last part of this paper. Hence, the raw data was analysed to obtain the percentages of the responses of all the respondents, The statement which was analysed for the purpose is the statement "Cloning is against religion". The result of the analysis is shown in table 1 .

Table 1. The percentages of the responses for all the respondents

\begin{tabular}{lllll}
\hline & Frequency & Percent & Valid Percent & Cumulative Percent \\
\hline Strongly disagree & 81 & 2.1 & 4.2 & 4.2 \\
Disagree & 186 & 4.8 & 9.7 & 13.9 \\
Not sure & 537 & 13.9 & 27.9 & 41.8 \\
Agree & 504 & 13.0 & 26.2 & 68.0 \\
Strongly agree & 615 & 15.9 & 32.0 & 100.0 \\
\hline
\end{tabular}


Table 1 shows that $4.2 \%$ of the respondents strongly disagree with the statement, $9.75 \%$ disagree, $27.9 \%$ not sure, $26.2 \%$ agree and $32.0 \%$ strongly agree. In total $58.2 \%$ accepted the statement that cloning is against religion while $13.9 \%$ rejected the statement that human cloning is against religion. The percentages of the responses were converted into line graph as shown in figure 1.

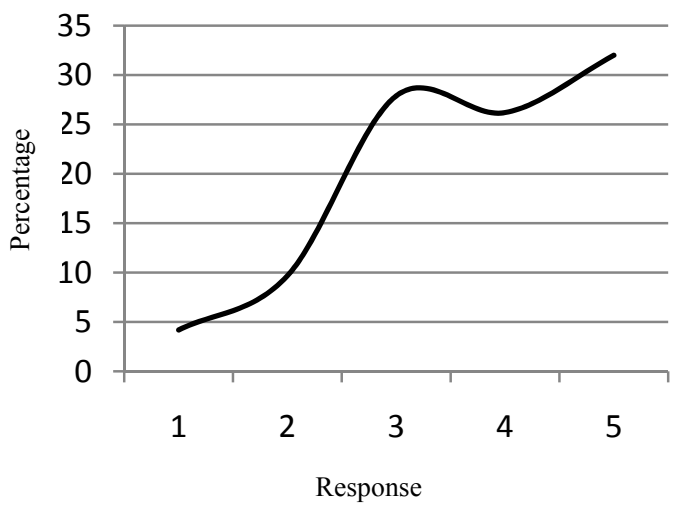

Figure 1. Line graph of the percentages of the response for all respondents

Figure 1 shows that the percentages of the responses gradually increases from 1 . Strongly disagree, to 2 , agree 3 . Not sure 4, agree and 5. Strongly agree. Furthermore, the next analysis is to obtain the mean of the response. The mean of the response is shown in table 2 .

Table 2. The mean response of all the respondents

\begin{tabular}{lllll}
\hline $\mathrm{N}$ & Minimum & Maximum & Mean & Std. Deviation \\
\hline 1920 & 1.00 & 5.00 & 3.7207 & 1.13538 \\
1929 & & & & \\
\hline
\end{tabular}

Table 2 shows that the mean response of all the respondent is 3.7207. The mean response lies between response 3 (not sure) and 4 (agree). Although the mean response indicates that the respondents agree with the statement that "cloning is against religion", the response is not strong. In addition, the next analysis is to analyse the percentages of the response according to the religion of the respondents. Table 3 shows the percentage of the responses according to the religion of the respondents.

Table 3. Percentages of the response according to the religion of the respondents

\begin{tabular}{ccccccccc}
\hline & \multicolumn{2}{c}{ Muslim } & \multicolumn{2}{c}{ Christian } & \multicolumn{2}{c}{ Buddhist } & \multicolumn{2}{c}{ Hindu } \\
\hline & Freq & $\%$ & Freq & $\%$ & Freq & $\%$ & Freq & $\%$ \\
\hline Strongly disagree & 66 & 5 & 6 & 3.4 & 9 & 2.3 & 0 & 0 \\
Disagree & 96 & 7.3 & 30 & 16.9 & 33 & 12.1 & 27 & 19.1 \\
Not sure & 333 & 25.2 & 66 & 37.3 & 75 & 27.5 & 57 & 40.4 \\
Agree & 315 & 23.9 & 30 & 16.9 & 111 & 40.7 & 48 & 34.0 \\
Strongly agree & 521 & 38.6 & 45 & 25.4 & 45 & 16.5 & 9 & 6.4 \\
\hline & 1320 & 100 & 168 & 100 & 271 & 100 & 141 & 100 \\
\hline
\end{tabular}

Table 3 shows that $38.6 \%$ of the Muslim respondents strongly agree and $23.9 \%$ agree. in total $62.5 \%$ of the Malay respondents accept the statement which if interpreted means that $62.5 \%$ of the Muslim respondents perceived that human cloning is against religion, $25.2 \%$ was not sure and $12.2 \%$ rejected the statement, meaning 
they perceive that cloning is against religion.

As for the Christian, $25.4 \%$ strongly agree to the statement and $16.9 \%$ agree. In total, $42.3 \%$ of the respondent accept the statement that human cloning is against religion, $37.3 \%$ was not sure, $3.4 \%$ strongly disagree and $16.9 \%$ disagree. In total, $20.3 \%$ of the Christian respondents did not accept the statement and when interpreted, $20.3 \%$ of the Christian respondents did not perceive that human cloning is against religion.

The percentages of the Buddhists respondents who strongly agree with the statement is $16.5 \%$, agree $40.7 \%$, those who strongly did not agree was $2.3 \%$, disagree was $12.1 \%$ and not sure was $27.5 \%$. In total $57.2 \%$ of the respondents accepted the statement that human cloning is against religion. When interpreted, it means that $57.2 \%$ of the Buddhist respondent perceived that human cloning is against religion.

Moreover, the next analysis was done to obtain the mean response for the respondent base on the religion of the respondents. The result of the analysis are shown in table 4.

Table 4. The mean responses based on the religion of the respondents

\begin{tabular}{llll}
\hline Religion & Mean & $\mathrm{N}$ & Std. Deviation \\
\hline Islam & 3.8386 & 1320 & 1.16473 \\
Christian & 3.4407 & 177 & 1.14878 \\
Buddha & 3.5495 & 273 & 1.01394 \\
Hindu & 3.2766 & 141 & 0.85216 \\
\hline
\end{tabular}

Table 4 shows that the Muslim respondents show the greatest mean response which is 3.8386 , followed by the Buddhists respondents - 3.5495, then the Christian respondents-3.4407 and the last is the Hindu respondents-3.2766. The greater of the mean response and the stronger perception that human cloning is against religion. The mean responses show that the Muslim respondents show a stronger perception that human cloning is against religion, but do the difference of mean significant. To examine whether the mean difference are significant or not, t-test was used of the Muslim and the Christian respondents as shown in table 5.

Table 5. T-test between the response of the Muslim and the Christian respondents

\begin{tabular}{lllll}
\hline $\mathrm{F}$ & Sig. & $\mathrm{t}$ & $\mathrm{df}$ & Sig. (2-tailed) \\
\hline 0.008 & 0.927 & 2.468 & 497 & 0.014 \\
& & 2.495 & 74.903 & 0.015 \\
\hline
\end{tabular}

Table 5 shows that the p-value for the t-test at $95 \%$ significant level is 0.014 which is smaller than the critical value of 0.05 . This shows that the difference of mean between the Muslim respondents and the Christian respondents is significant. There is a difference between the Muslim respondents perception and the Christian respondents perception on human cloning.

In addition, the t-test between the Muslim respondents and the Buddhist respondents was also conducted, and the result of the test is shown in table 6 .

Table 6. T-test between the mean of the Muslim respondents and the Buddhist respondents

\begin{tabular}{lllll}
\hline $\mathrm{F}$ & Sig. & $\mathrm{t}$ & $\mathrm{df}$ & Sig. (2-tailed) \\
\hline 3.275 & 0.071 & 2.202 & 529 & 0.028 \\
& & 2.411 & 143.632 & 0.017 \\
\hline
\end{tabular}

Table 6 shows that the p-value at the $95 \%$ confidence limit i.e. 0.028 is less than the critical value of 0.05 and this indicate that the difference of mean between the Muslim and the Buddhists respondents is significant.

Furthermore, the t-test was also conducted between the Christian and the Buddhists respondents. The t-test result 
is shown in table 7.

Table 7. T-test between the mean of the Christian and the Buddhist respondents

\begin{tabular}{lllll}
\hline $\mathrm{F}$ & Sig. & $\mathrm{t}$ & $\mathrm{df}$ & Sig. (2-tailed) \\
\hline 2.134 & 0.146 & -0.609 & 148 & 0.544 \\
& & -0.593 & 112.836 & 0.554 \\
\hline
\end{tabular}

Table 7 shows that the p-value at $95 \%$ confidence limit is 0.544 which is bigger than the critical value of 0.05 and this means that the mean difference between the response of the Christian and the Buddhist respondents is not significant.

T-test was also conducted between the mean response of the Muslim and the Hindu respondents. The result of the test is shown in table 8 .

Table 8. T-test between the mean of the Muslim and the Hindu respondents

\begin{tabular}{lllll}
\hline $\mathrm{F}$ & Sig. & $\mathrm{T}$ & $\mathrm{df}$ & Sig. (2-tailed) \\
\hline 7.542 & 0.006 & 3.216 & 485 & 0.001 \\
& & 4.128 & 65.915 & 0.000 \\
\hline
\end{tabular}

Table 8 shows that the p-values at the $95 \%$ confidence limit is smaller that the critical value 0.05 . the $p$ value is very much smaller than the $p$-value of the test between the mean response of the Muslim respondents and the mean response of the Christians and Buddhists respondents.

\section{Discussion}

The study on the perception of human cloning among the Malaysian respondents shows that $58.2 \%$ of the respondents perceived that human cloning is against religion. Therefore it can be assumed that less than $60 \%$ perceived that human cloning is against religion, where percentages of response base on the religion of the respondents show the Muslim represent $62.5 \%$, the Christian respondents represent $42.3 \%$, the Buddhists respondents represent $57.2 \%$ and the Hindu respondents represent $40.4 \%$. These indicate that the perception of the people on the human cloning is different from a religion to another. However the finding of the study affirm what has been said by Sweetman (2009) that the society is equally split on the issue of human cloning. Hence, the finding of the study has also affirmed what Roetz (2006) claimed in his work that adherents to one and the same ethical tradition like Confucianism, Buddhism and Islam can come to diverging opinion on human cloning.

The percentage of the respondents who accepted that human cloning is against religion is about the same percentage with those who were not sure or who rejected that human cloning is not against religion, especially among the non Muslim i.e. the Christians, the Buddhists and the Hindu. This indicate that among the non-Muslim, the perception on human cloning are equally split between rejection, acceptance and indecision.

The Muslim respondents are the strongest objectors of human cloning (mean response is 3.8386) and the highest percentage of the respondents who accepted the statement that human cloning is against religion which is $62.5 \%$. It could be understood why the majority of the Muslim respondents objected the human cloning.

The Islamic law stated very clearly that the act of human being falls under five categories of rules i.e. haram (forbidden), wajib (compulsory), sunnat (encouraged), makruh (not encouraged) and harus (permissible). The ruling on human cloning is derived from the analysis whether the act of cloning human fall under what is termed as maqasid shariah (The aim of the Islamic laws) in which among others is the protection of life and also the protection of human dignity (Sait \& Lim, 2006).

The National Council of Fatwa Malaysian proclaimed that human cloning is not permissible in Islam i.e. haram but allows stem cell research which are meant for medical purposes and only involving embryos which are less than 120 days old (Knowles et al., 2007). Although the organised religions such as Islam and Christianity rejected human cloning for reproduction purposes, Buddhism on the other hand accepted human cloning (Roetz, 2006). On the other hand, Hinduism does not give explicit answer whether yes or no to human cloning (Beck \& Worden, 2001). The perception of the people toward human cloning seems to be different from each other. One 
of the reason why the Muslim seems to be the most reluctant group to accept human cloning is because the Muslim in Malaysia are constantly being exposed to the issue through the mass media which frequently discuss the issue and most of the Muslim undergo religious education formally in schools where Islam is thought as a compulsory subject, and it is thought in the mosques informally. The religious education which they received determine their perception on human cloning. The other faiths, i.e. Christianity, Buddhism and Hinduism are not thought formally at school and the issue of human cloning in these religion is not widely discussed in the mass media like Islam.

\section{References}

Beck, R., \& Worden, D. (2001). Truth, Spirituality and Contemporary Issues. London: General Certificate of Education.

Johnson, J. A. (2011). Human Cloning. Pennsylvania: Diane Publishing.

Knowles, L. P. (2007). Reprogenetics: Law, Policy, and Ethical Issues. Maryland: JHU Press.

Lauritzen, P. (2001). Cloning and the Future of Human Embryo Research. Oxford: Oxford University Press.

MacKinnon, B. (2000). Human Cloning: Science, Ethics, and Public Policy. Urbana, Chicago: University Illinois Press.

McLaren, A. (2002). Cloning. Strasbourg: Council of Europe.

Pence, G. E. (1998). Who's Afraid of Human Cloning? Maryland: Lanham.

President's Council on Bioethic. (2002). Human Cloning and Human Dignity: An Ethical Inquiry. Washington D.C: Government Printing Office.

Roetz, H. (2006). Cross-cultural Issues in Bioethics: The Example of Human Cloning. Amsterdam: Rodopi.

Sachedina, A. (2009). Islamic Biomedical Ethics: Principles and Application: Principles and Application. Oxford: Oxford University Press. http://dx.doi.org/10.1093/acprof:oso/9780195378504.001.0001

Sait, S., \& Lim, H. (2006). Land, Law and Islam: Property and Human Rights in the Muslim World. London: Zed Book.

Sweetman, B. (2009). Religion and Science: An Introduction. New York: The Continuum International Publishing Group. Inc.

Torremans, P. (2008). Intellectual Property and Human Rights. The Netherland: Kluwer Law International.

Turner, R. C. (2007). Human Cloning: Religious Responses. Kentucky: John Knox Press.

\section{Copyrights}

Copyright for this article is retained by the author(s), with first publication rights granted to the journal.

This is an open-access article distributed under the terms and conditions of the Creative Commons Attribution license (http://creativecommons.org/licenses/by/3.0/). 